\title{
Estimation of Species Richness of Permian Foraminifera in Non-Parametric Methods and Investigation of Its Change Trend in Central Alborz, Western Tethys
}

\author{
Mohammad Medadi', Hossein Mosaddegh ${ }^{2}$, Seyed Mohsen Aleali ${ }^{*}$, Mahmoud Reza Majidifard ${ }^{4}$ \\ ${ }^{1}$ Department of Geology, Science and Research Branch, Islamic Azad University, Tehran, Iran \\ ${ }^{2}$ Department of Geology, Faculty of Earth Sciences, Kharazmi University of Tehran, Iran \\ ${ }^{3}$ Department of Geology, Science and Research Branch, Islamic Azad University, Tehran, Iran \\ ${ }^{4}$ Research Institute for Earth Sciences in Geological Survey of Iran, Tehran, Iran \\ Email: mohamad.medadi@srbiau.ac.ir, mossaddegh@khu.ac.ir, *aleali.mohsen@gmail.com,m_majidifard@yahoo.com
}

How to cite this paper: Medadi, M., Mosaddegh, H., Aleali, S.M. and Majidifard, M.R. (2017) Estimation of Species Richness of Permian Foraminifera in Non-Parametric Methods and Investigation of Its Change Trend in Central Alborz, Western Tethys. Open Journal of Geology, 7, 666-682. https://doi.org/10.4236/ojg.2017.75045

Received: December 26, 2016

Accepted: May 21, 2017

Published: May 24, 2017

Copyright (c) 2017 by authors and Scientific Research Publishing Inc. This work is licensed under the Creative Commons Attribution International License (CC BY 4.0).

http://creativecommons.org/licenses/by/4.0/

\begin{abstract}
Species richness of foraminifera assemblages in the Permian succession, contains Dorud, Ruteh and Nessen Formations, in Central Alborz-North of Iran, was estimated and studied based on lithostratigraphy and microbiostratigraphy of Permian. We used four non-parametric estimators to investigate the species richness: Chao 2, Jackknife 1, Jackknife 2 and bootstrap. These methods estimates the species richness based on the presence/absence data of each taxon identified in the samples. We use the submenu of quadrat richness in "Past" [1] software to estimate richness in regional chronostratigraphic stages.The results show that the estimated diversity of foraminiferal assemblages with the exception of late Yakhtashian, increased constantly from Asselian to Murgabian with the highest diversity of foraminifera seen in the Murgabian. The main decrease in foraminiferal species richness happened during the Midian which corresponds to the kamura cooling event.
\end{abstract}

\section{Keywords}

Permian, Foraminifera, Species Richness, Central Alborz, Western Tethys

\section{Introduction}

The number of species in a community and their relative abundance is defined as species diversity [2] [3]. Whittaker [4] introduced three diversity indices in relation to the environment and communities:

1) Alpha diversity: the local, in-habitat diversity, often estimated based on one 
sample.

2) Beta diversity: shows species composition changes within a community or in a gradient [5] or along with changes in a variety of habitats [6].

3) Gamma diversity: this is defined as inter-province (across regions diversity) [7].

Species richness is a numerical index and shows measure of alpha diversity. This means that to calculate it, the number of each species (number of individuals) in the samples is used. But, there are also other non-parametric methods for the calculation of richness that is used in this study. In these methods, the number of individuals is not need to calculate richness.

There are many examples of the application of this index in palaeontology. Sepkoski [8] used richness at two genus and family levels for Phanerozoic marine animals and utilized the method of counting the number of taxa. Bentone [9] chose family taxonomic level for his study and used the number of family as richness index. Ruban [10] studies biodiversity of Jurassic foraminifera in northern Kazakhstan at the level of genus and species. Uhen [11] used the number of genera as amount of richness. Vilhena [12] measured species richness by counting the presence or absence of genera in intervals and compared it at palaeo latitudes. Ruban [13] used a similar method to calculate the richness of the Jurassic brachiopods. In this study species richness of Permian foraminifera is estimated from four important non-parametric methods including Chao 2, Jackknife 1, Jackknife 2 and bootstrap [7]. In these methods, richness estimated without counting the number of species in samples, but based on the presence/absence of each taxon in the samples. For this purpose, two outcrops of the Permian strata were selected in Central Alborz and they litho and biostratigraphy was studied at high resolution. The species richness of the recovered for aminiferal assemblages was estimated using presence/absence data of the identified taxa in samples during regional chronostratigraphic (stage and sub stage) intervals.

\section{Geographic, Geological and Palaeogeographic Setting}

\subsection{Geographic Setting}

Alborz Mountains extend with a W-E trend along north of Iran. The two studied outcrops are located in the central part of Alborz. The first one is the type section of the Dorud Formation [14], located at north of the Dorud village. It lies north of Tehran (Figure $1(\mathrm{c})$ ) with the geographic coordinates: $36^{\circ} 00^{\prime} 18.48^{\prime \prime} \mathrm{N}$ and $51^{\circ} 29^{\prime} 04.33^{\prime \prime} \mathrm{E}$ at the base of section. It was studied with the aim for capturing data from the Dorud Formation (lower Permian). The Dorud type section can be accessed by the main Tehran-Shemshak-Dizin road. The second outcrop contains one of the greatest thicknesses of Ruteh Formation in Central Alborz and is located NW of Heev town and SE of Gazvin. It has been studied for Middle Permian (Ruteh Formation) and Upper Permian (Nessen Formation) Fuana. This outcrop has the geographic coordinates $36^{\circ} 04^{\prime} 35.92^{\prime \prime} \mathrm{N}$ and $50^{\circ} 39^{\prime} 1730^{\prime \prime} \mathrm{E}$ at the base of section. Heev is accessed by the main asphalt road branching at 23th 


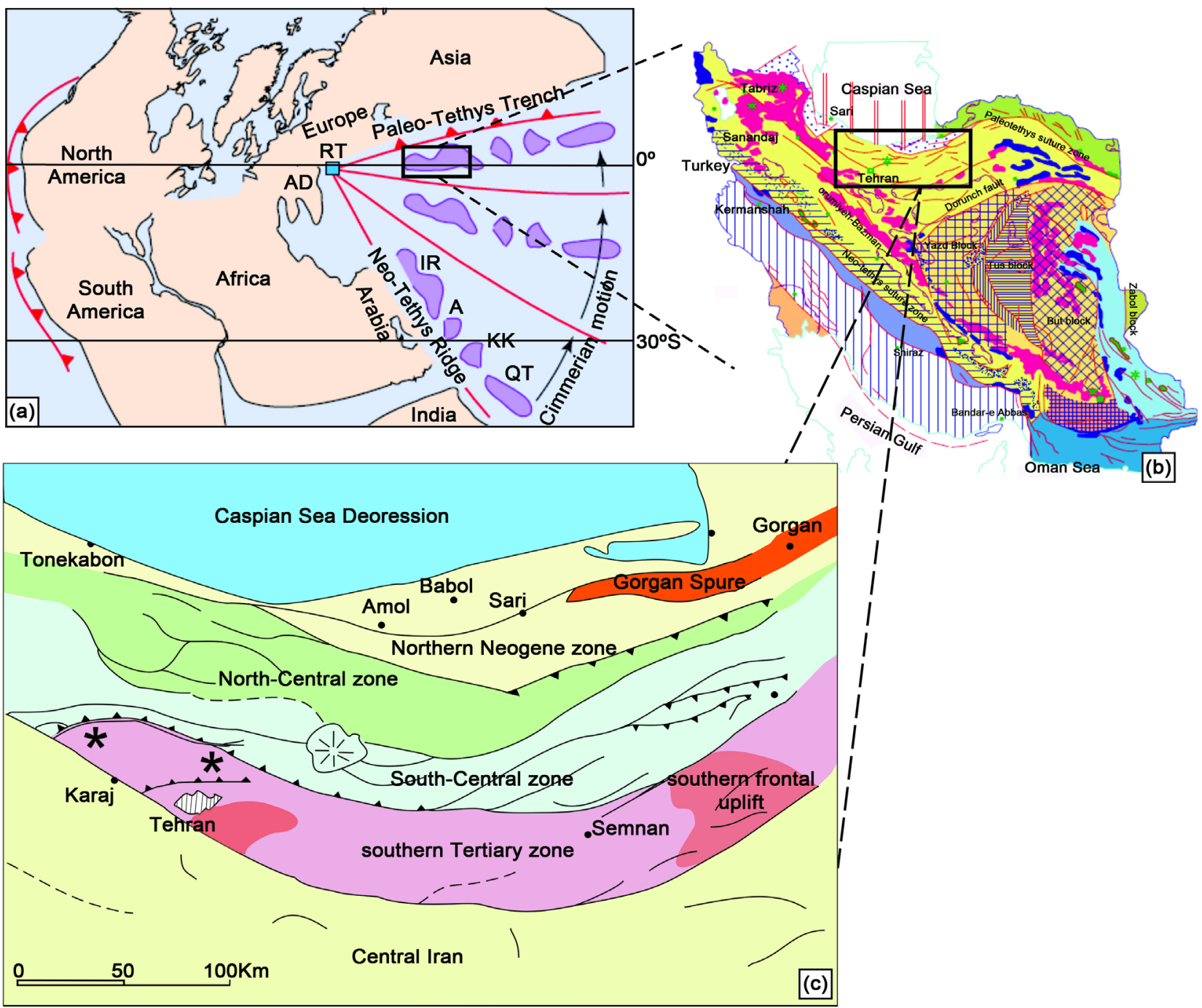

Figure 1. (a) Paleogeographic location of Iranian plate and its motion along with Cimmerian terranes during Permian-Triassic, adapted from [19]. (b) Main tectono-stratigraphic units of Iran, adapted from [14]. (c) Tectono-stratigraphic subdivision of Central Alborz, major faults and thrusts, modified from [18]. $\left(^{*}\right)$ shows location of studied sections.

Km from Karaj-Gazvin highway. The section can be acsessed then by a roadway from Heev to Emamzadeh-Musa to the north.

\subsection{Geological Setting}

The Heev section is situated at the western margin and the Dorud section approximately in the center of Central Alborz representing the middle part of Alborz Mountains in the north of Iran. Aghanabati [15] divided the Iranian platform into three tectono-stratigraphic units including Northern Iran (Turan plate), Central Iran (Iranian plate) and Southern Iran (Zagros plate) by considering two main geo sutures: Palaeo-Tethys and Neo-Tethys (Figure 1(b)). In this subdivision, Central Iran plate contains several zones and subzones and one of them is the Alborz-Azerbaijan zone which is known as Alborz Block or Alborz Terrane too [16]. The Alborz Mountains according to [15] and [17] can be subdivided into three main subunits containing the Western, Central and East- 
ern Alborz. The central Alborz is showing W-E structural trend and can be further divided into six subzones based on main faults and thrusts [18] (Figure 1(c)). Our studied sections are located at the southern Central subzone.

\subsection{Palaeogeographic Setting}

According to [19] the Alborz Mountains along with Central Iran, Sanandaj-Sirjan and NW Iran are comprising the Iranian plate since the early Permian and were disrupted from the Arabian plate by opening of the Neo-Tethys Ocean. This opening led to the formation of Cimmerian continents (Pangaea B) and spreading caused the motion of Iran, Afghanistan and other fragments toward NE (Figure 1(a)). Along with the opening of Neo-Tethys, subduction took place along the Palaeo-Tethys suture. Investigation of palaeomagnetic changes in the Central Alborz-Aru region by [19] shows that the Iranian plate were situated around $20^{\circ} \mathrm{S}$ with a North-South trend in the Early Permian. During opening the Neo-Tethys and simultaneous Palaeo-Tethys subduction, it started to move to north rotating counter clockwise at the same time. So, during Late Permian it was placed in tropical latitude with a WE trend (Figure 1(a)).

\section{Discussion and Methods}

To investigate the species richness of foraminifera, two sections of the Permian succession in Central Alborz have been selected and sampled systematically. Whereas biodiversity is a characterized by ecological and geological factors [20] and geological factors mainly contain fossil and rock records in palaeontology, so it is very important in palaeobiodiversity studies that selected data resources be perfect indicator of main diversity. In other word only perfect rock and fossil record can be representative of biodiversity at geological time. Hence we selected two studied sections by considering these two principals: rock and fossil record and by investigating all the previous studies. In addition since palaeobiodiversity can be considered as a basin scale study, so we did not have any restriction to select separated section for various intervals. As said above, Heev section is one of the thickest Ruteh outcrops (perfect rock record) in Central Alborz and have an acceptable fossil record of foraminifera according to previous studies such as [21]. However in the Heev section, Dorud Formation though having great thickness does not contain all of the distinguished foraminifera biozones. Therefore we selected another and better section that has a more perfect fossil record.

After preparation of thin sections we studied them micropalaeontologically. We identified all foraminifer genera and species in thin sections and then drew their extension line in a lithostratigraphic column (rang chart). Biostratigraphy is done based on lithostratigraphy and extension of taxa and index genus and species. We separated Permian stages (Asselian to Dzhulfian) and then inserted presence/absence data of taxa in Past [1] software data sheet (Table 1 and Tables 2(a)-2(f) see Appendix). So we could estimate species richness in four methods by quadrat submenu of diversity menu in Past [1] and then we plotted them in a curve diagram by using Excel. 


\section{Lithostratigraphy}

\subsection{Dorud Section}

The type section of the Dorud Formation (or Dorud Group as recommended by [22]) (Figure 2(e)) in north of the Dorud village disconformably overlies limestone of Carboniferous Mobarak Formation. The Permian succession in this section has a total thickness of $248 \mathrm{~m}$ includes the Dorud $(168 \mathrm{~m})$ and Ruteh $(80 \mathrm{~m})$ formations. On top the contact with the Shemshak Formation is detached by a fault and a large portion of Ruteh and all of Nessen Formation are absent in this section. The Dorud Formation in this section contains four lithologic members recommended by Assereto [14] include: 1; thin bedded shaly marl alternating with limestone and protoquartzite, 2 ; laminated reddish shale with a basal conglomerate, 3; fossiliferous massive oncoidal limestone with fusulinids, 4; reddish siltstone alternating with laminated shale and red sandstone (Figure 2(e) and Figure 3).
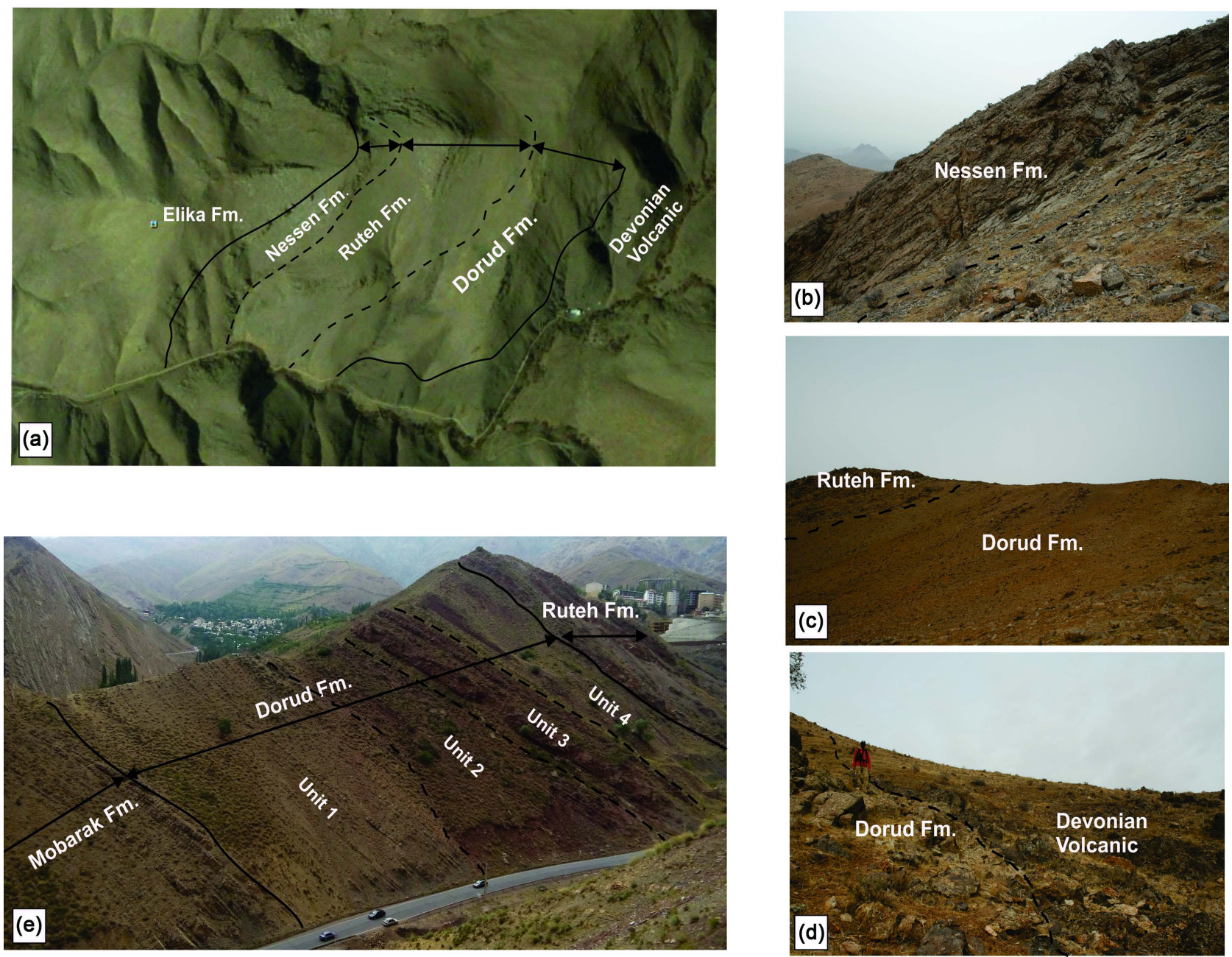

Figure 2. (a)-(d) Heev section, (e) Dorud section, outcrop details: (a) view of Heev section adapted from Google Earth, (b) contact of Ruteh and Nessen Formations at Heev section, (c) unconformable contact of Ruteh and Dorud Formations at Heev section, (d) eroisonal contact of Devonian volcanic unit with basal conglomerate of Dorud Formation at Heev section, (e) members of Dorud Formation at studied section (type section of Dorud Formation, north of Tehran). 


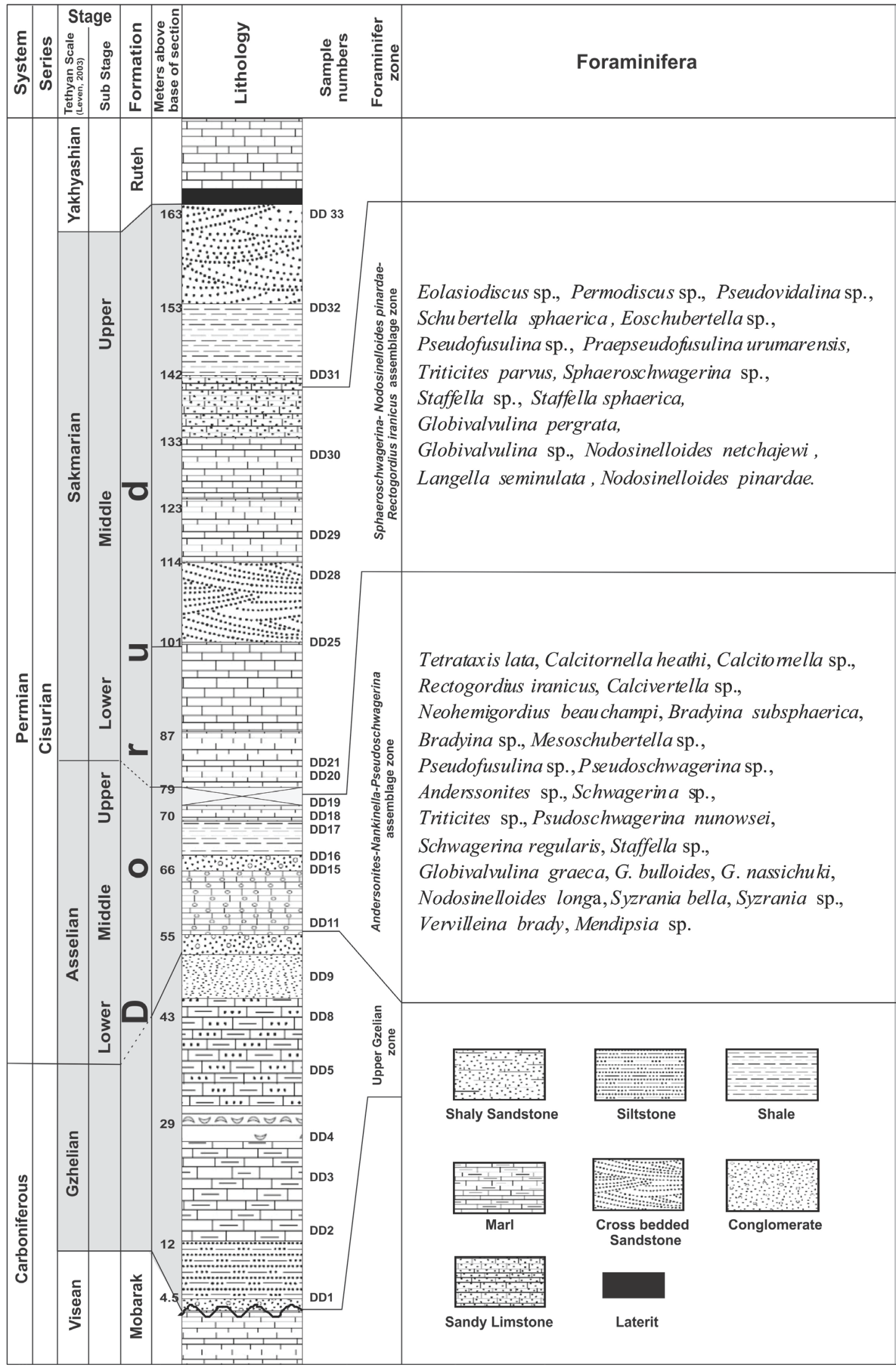

Figure 3. Stratigraphic log of the Dorud Formation in Dorud Section, Central Alborz, North of Tehran, with foraminiferal biozones. 


\subsection{Heev Section}

The Permian outcrop in the Heev section includes The Dorud, Ruteh and Nessen formations (Figure 2(a)) attaining a total thickness of $585 \mathrm{~m}$. The Permian succession is underlain by dark volcanic unit of Jeirud Formation (Devonian) with a nonconformity contact (Figure 2(d)). Above, it is covered by a vermiculite, thin bedded limestone of the Elika Formation (Triassic) with a disconformity contact (Figure 2 and Figure 4).

The Dorud Formation $(243 \mathrm{~m}$ ) begins with a basal fine grained conglomerate changing upward into a quartzitic weathering buff colored sandstone followed by cross bedded sandstone, silty and shaly sandstone, Fusulinid and oncoid bearing gray limestone and massive thick bedded sandstone are present in the uppermost part. We did not study the Dorud Formation in this section because of its incomplete microfauna.

The transition to the Ruteh Formation $(314 \mathrm{~m})$ in the studied section disconformably overlies reddish brown Laterite zone on top of the Dorud Formation. The Ruteh Formation typically contains dark gray fossiliferous limestone bearing common macrofauna of brachiopods, corals, trilobites and Zoophycus trace fossils (Figure 4).

The Ruteh Formation is followed dark gray limestone $(28 \mathrm{~m})$ of Nessen Formation. The contact is disconformable because of laterite zone in between.

\section{Biostratigraphy}

To estimate the species richness in stages we used Tetyan stages defined by Leven [23] and defined regional substages and biozones in this study. Due to the scarce presence of larger foraminifera, smaller foraminifera have been preferentially used for Permian biostratigraphy in Central Alborz [24]. For our investigation, we used previous studies and suggested biozones such as: [21] [23]-[29]. We identified about 200 foraminifera taxa and drew their range chart and then separated stages from Asselian to Dzhulfian by using index taxa and biozones (Figure 3 and Figure 4). We used or defined 9 biozones for studied Permian succession as follow:

(1) Nankinella-Anderssonites-Pseudoschwagerina assemblage zone (Dorud Formation; Asselian); The age of the Dorud Formation is Gzhelian (Uppermost Carboniferous) to Sakmarian according to [14] [22] [28]. The lower beds (50 m) of the Dorud Formation may belong to Gzhelian. The first evidence of Permian foraminifera is in sample No. D11 with Nankinella, followed by some other taxa such as Anderssonites (sample No. D12) and Praeopseudofusullina (sample No. D13). FOD of Pseudoschwagerina indicate middle Asselian deposits [22] [30]. Other taxa of the Asselian assemblage are: Tetrataxis lata, Calcitornella heathi, Calcitornella sp., Rectogordius iranicus, Calcivertella sp., Neohemigordius beauchampi, Bradyina subsphaerica, Bradyina sp., Mesoschubertella sp., Pseudofusulina sp., Pseudoschwagerina sp., Anderssonites sp., Schwagerina sp., Triticites sp., Psudoschwagerina nunowsei, Schwagerina regularis, Staffella sp., Globivalvulina graeca, G. bulloides, G. nassichuki, Nodosinelloides longa, Syzrania bella, Syzrania sp., Vervilleina brady, Mendipsia sp. (Figure 5, Plate 1). 


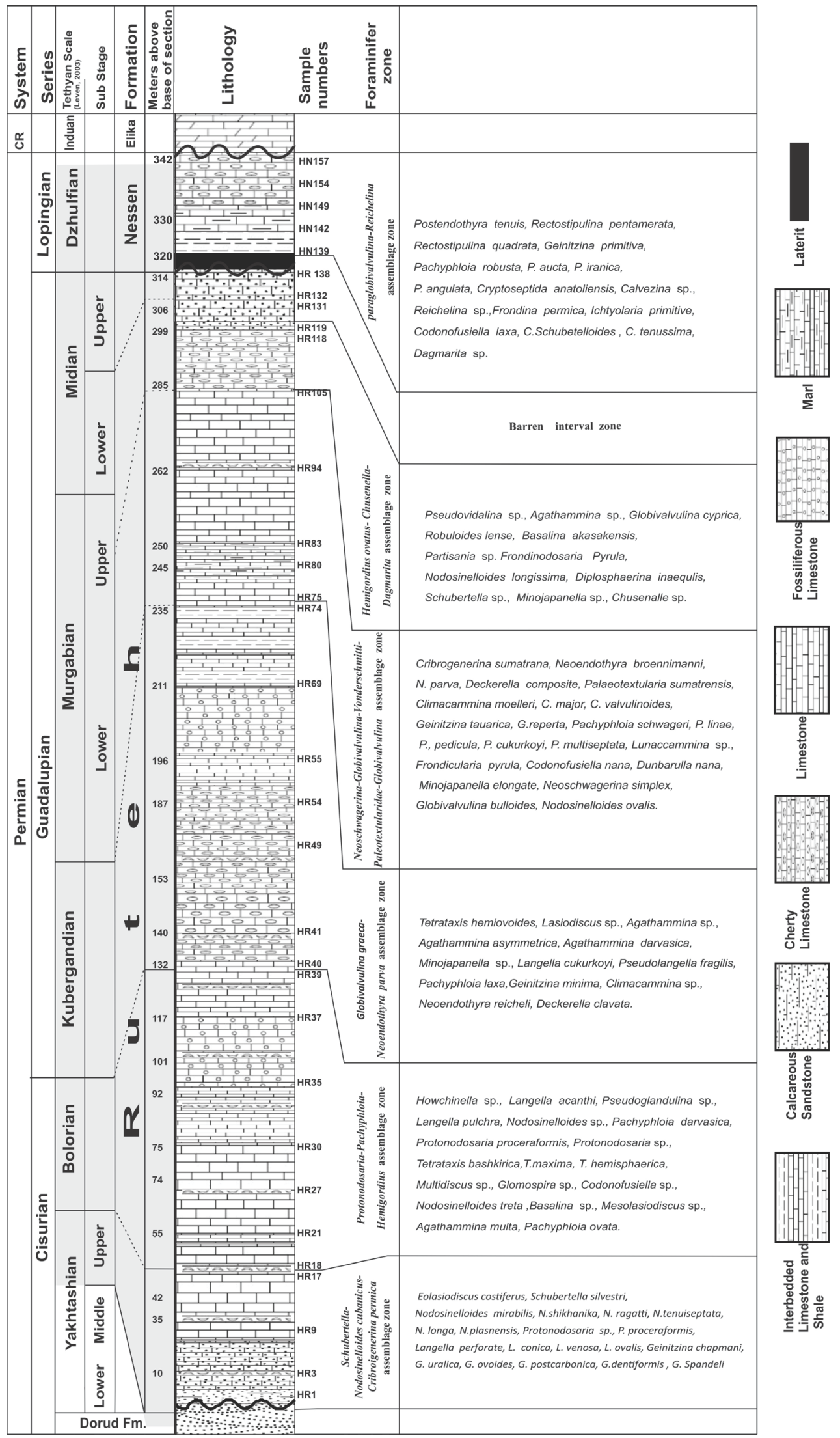

Figure 4. Stratigraphic log of the Ruteh and Nessen Formations in Heev Section, Central Alborz, SE of Gazvin with foraminiferal biozones. 


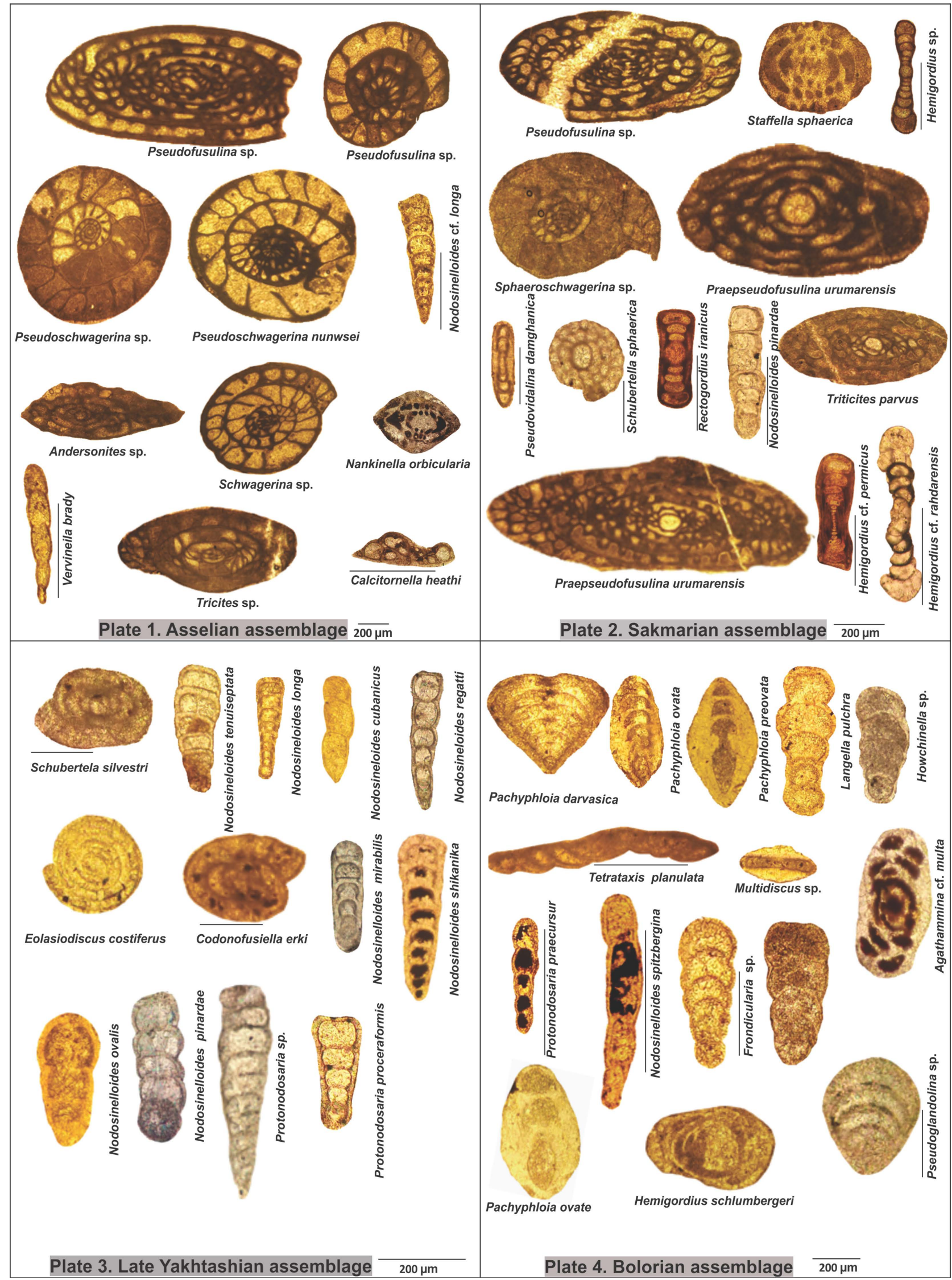

Figure 5. Plate of foraminifera. 
(2) Sphaeroschwagerina-Nodosinelloides pinardae-Rectogordius iranicus assemblage zone (Dorud Formation; Sakmarian); Some important genera and species appearances take place in this stage: Nodosinelloides pinardae and Deckerella elegans [31], Mesolasiodiscus costiformis [29], Rectogordius iranicus [32]. FAD of Sphaeroschwagerina is Asselian, but there are few species which range into early Sakmarian [22]. The other attendant taxa of the Sakmarian assemblage are: Eolasiodiscus sp., Permodiscus sp., Pseudovidalina sp., Schubertella sphaerica, Eoschubertella sp., Pseudofusulina sp., Praepseudofusulina urumarensis, Triticites parvus, Sphaeroschwagerina sp., Staffella sp., Staffella sphaerica, Globivalvulina pergrata, Globivalvulina sp., Nodosinelloides netchajewi, Langella seminulata, Nodosinelloides pinardae (Figure 5, Plate 2).

(3) Schubertella-Nodosinelloides cubanicus-Cribroigenerina permica assemblage zone (Ruteh Formation; late Yakhtashain); Before description of mid Permian biozonation, an important discussion about beginning age of Ruteh Formation must be considered. Despite many authors infer a Kubergandian or Murgabian age for the onset of deposition in the Ruteh Formation in Central Alborz [22], some studies have shown that the base of Ruteh Formation might be older. Vaziri [33] reported an Artinskian age of the Ruteh Formation in the Abyek-Gazvin area based on micropalaeontology. Again, Vaziri [21] accommodated themselves previous results with Radiolarian biozones in our studied area and the most important record belong to [34] who identified and reported Sweetognathus wheitei Biozone, conodont index of Artinskian stage in Global Boundery Stratotype Section and Point (GSSP). So it is conspicuous that base of Ruteh Formation is diachronic and in our studied area bearing smaller foraminifera belong to late Yakhtashian such as Schubertella and Mesoschubertella [33], Nodosinelloides cubanicus [31], Cribrogenerina permica [29]. This assemblage appertains to the late Yakhtashian because of the appearance of mentioned taxa and abundance of Lagenoida up to $100 \%$ [31] and does not belong to the Bolorian due to the absence of Pachyphloidae. Also, absence of early Yakhtashian index Climacammina and Cribrogenerina shows the lack of this substage. This assemblage contain: Eolasiodiscus costiferus, Schubertella silvestri, Nodosinelloides mirabilis, $N$. shikhanika, $N$. ragatti, $N$. tenuiseptata, $N$. longa, $N$. plasnensis, Protonodosaria sp., P. proceraformis, Langella perforate, L. conica, $L$. venosa, L. ovalis, Geinitzina chapmani, G. uralica, G. ovoides, G. postcarbonica, G. dentiformis, G. Spandeli (Figure 5, Plate 3).

(4) Protonodosaria-Pachyphloia-Hemigordius assemblage zone (Ruteh Formation; Bolorian); Bolorian is distinguished with decrease of Lagenoida abundance [31] and appearance of Pachyphloia such as $P$. ovata, $P$ darvasica, $P$. paraovata. Other taxa that this assemblage consist are: Howchinella sp., Langella acanthi, Pseudoglandulina sp., Langella pulchra, Nodosinelloides sp., Pachyphloia darvasica, Protonodosaria proceraformis, Protonodosaria sp., Tetrataxis bashkirica, T. maxima, T. hemisphaerica, Multidiscus sp., Glomospira sp., Codonofusiella sp., Nodosinelloides treta, Basalina sp., Mesolasiodiscus sp., Agathammina multa, Pachyphloia ovate (Figure 5, Plate 4). 
(5) Globivalvulina graeca-Neoendothyra parva asssemblage zone (Ruteh Formation; Kubergandian); We remarked lower boundary of Kubergandian with Globivalvulina graeca-Neoendothyra parva biozone, represented by [25]. Filimonova [29] suggested Rectoglandulina biozone for Kubergandian of western Tethys that we identified two species from it. This assemblage consist:

Tetrataxis hemiovoides, Lasiodiscus sp., Agathammina sp., Agathammina asymmetrica, Agathammina darvasica, Minojapanella sp., Langella cukurkoyi, Pseudolangella fragilis, Pachyphloia laxa, Geinitzina minima, Climacammina sp., Neoendothyra reicheli, Deckerella clavata (Figure 6, Plate 5).

(6) Neoschwagerina-Globivalvulina Vonderschmitti Paleotextularidae assemblage (Ruteh Formation; Murgabian); Kubergandian-Murgabian boundary characterized by appearance of lower Murgabian taxa such as Neoschwagerina [23] [33] [35]. The accompany assemblage that aged early Murgabian consist Dunbarula, Biseriaminidae [22], Cryptoseptida, Lunaccammina, Frondinodosaria [24]. Upper Murgabian characterized by assemblage that consist: Neoendothyra [33], Paleotextularidae [22], Globivalvulina vondershmitti [25]. Some other species of Murgabian assemblage are: Cribrogenerina sumatrana, Neoendothyra broennimanni, N. parva, Deckerella composite, Palaeotextularia sumatrensis, Climacammina moelleri, C. major, C. valvulinoides, Geinitzina tauarica, G. reperta, Pachyphloia schwageri, P. linae, P. pedicula, P. cukurkoyi, P. multiseptata, Lunaccammina sp., Frondicularia pyrula, Codonofusiella nana, Dunbarulla nana, Minojapanella elongate, Neoschwagerina simplex, Globivalvulina bulloides, Nodosinelloides ovalis (Figure 6, Plate 6).

(7) Hemigordius ovatus-Chusenella-Dagmarita assemblage zone (Ruteh Formation; Early Midian); Midian index taxa are: Hemigordius ovatus [26], Dagmarita [25], Codonofusiella erki [16], Chusenella [33]. Other taxa accompanied assemblage are: Pseudovidalina sp., Agathammina sp., Globivalvulina cyprica, Robuloides lens, Basalina akasakensis, Kahlerina sp., Paraglobivalvulina mira, P. sp., Partisania sp., Frondinodosaria Pyrula, Nodosinelloides longissima, Diplosphaerina inaequlis, Pseudolangella bozorgniaeb (Figure 6, Plate 7).

(8) Barren interval zone (Ruteh Formation; late Midian?); From biostratigraphy aspect the latest part of Ruteh Formation at studied section belongs to Midian and, a few meters of sandy limestone and sandstone that is very poor from foraminifera fauna distinguished under the top of Formation that can be assigned to late Midian and corresponded with End-Guadalopian extinction.

(9) paraglobivalvulina-Reichelina assemblage zone (Nessen Formation; Dzhulfian); As mentioned upper Permian identified by Nessen Formation in Alborz and it differentiates from Ruteh Formation by a Bauxit-Laterit zone usually and at studied section too. We aged Nesen Formation early to late Dzhulfian that characterize by Reichelina [22] [33] [36], Robuloides and Ichtyolaria [24], Rectostipulina [24] [27] [33]. This biozone contains other taxa such as: Postendothyra tenuis, Rectostipulina pentamerata, Rectostipulina quadrata, Postendothyra novitzkiana, Geinitzina primitiva, Pachyphloia robusta, P. aucta, P. iranica, P. angulata, Cryptoseptida anatoliensis, Calvezina sp., Reichelina sp., Calvezina 


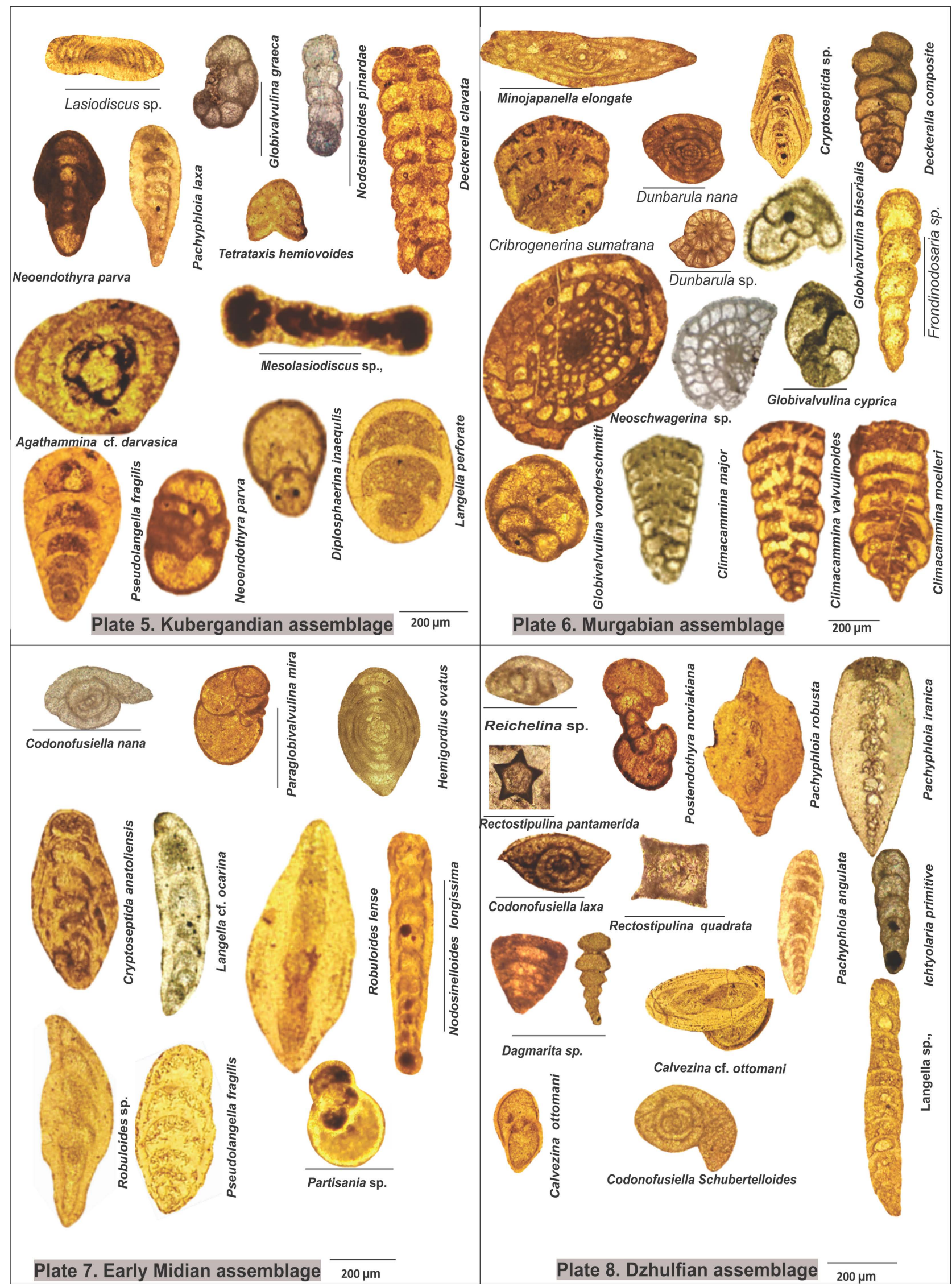

Figure 6. Plate of foraminifera. 
ottoman, Frondina permica, Ichtyolaria primitiva, Codonofusiella laxa, C. schubetelloides, C. tenussima, Dagmarita sp. (Figure 6, Plate 8). We did not have any evidence for Dorashamian age in Nessen Formation rocks.

\section{Species Richness Measurement Method}

There are different methods to measure species richness. In the simplest case, it is equal to the number of observed species in the sample: $\mathrm{R}=\mathrm{S}$ where $\mathrm{R}$ is richness and $S$ is number of species counted in samples. However there are many examples of using other taxonomic levels in palaeontology. Two general approaches to calculate (estimate perhaps better expression) index there are: (1) by measuring the presence or absence of species in samples and (2) by counting the number of individuals of each species (abundance) in samples. We used the first method, where some random standard samples are selected and then species presence/absence data are extracted and richness in total of samples is calculated. The four important equations for richness calculation in this method are [7]:

1) Chao $2=S_{o b s}+L^{2} / 2 M$

2) Jackknife $1=S_{o b s}+L(n-1) / n$

3) Jackknife $2=S_{o b s}+L(2 n-3) / n-M(n-2)^{2} /\left(n^{2}-n\right)$

4) Boot strap $=S_{o b s}+\sum\left(1-P_{i}\right)^{2}$

where:

$S_{o b s}$ : total number of observed species

$L$ : the number of species that are present in a sample

$M$ : the number of species that exist in the two samples

$P_{i}:$ proportion of specimens containing species i

$n$ : the number (size) of samples

To estimate the indices with "Past" software [1] each row appropriates to a taxon and each column to a sample (represented by one? thin section in this study) and then the presence/absence of each taxon in each sample is entered in the relevant box. After entering all data (Table 1 and Tables 2(a)-2(f) see Appendix) and according to the range chart, columns (samples) of each stage were selected and grouped in the data sheet. In this step "Past" software [1] can estimate the above mentioned indices in species richness menu and quadrate submenu. The results for the Asselian through Dzhulfian stages are displayed in Table 3 and Figure 7 shows the curve diagram of them. Note that "Past" output for each quadrate (here is stage or substage) includes two groups of richness amounts: Original data set and Bootstrap replicates. Although there is little difference in numerical amount of the four indices and between two mentioned groups for each interval, all of them showing a similar trend.

\section{Conclusion}

The trend of species richness shows that all of four computational approaches have quite similar trends and slight differences in their amounts are the result of different equations used. The chart is showing a species richness increase from Asselian to Murgabian with a maximum value in the Murgabian. This is comparable 
Table 3. Foraminifera species richness measures obtained from Past [1] for Asselian to Dzhulfian based on data extracted from studied sections.

\begin{tabular}{ccccc}
\hline STAGE/INDICES & Chao 2 & Jackknife 1 & Jackknife 2 & Bootstrap \\
\hline Asselian & 39.5583 & 43.05 & 40.3183 & $\mathbf{3 9 . 5 8 2 9}$ \\
Sakmarian & 48.7298 & 53.9491 & 51.6023 & $\mathbf{5 0 . 6 2 7 4}$ \\
Late Yakhtashian & 36.9017 & 40.5877 & 39.8958 & $\mathbf{3 6 . 5 1 3 9}$ \\
Bolorian & 40.3577 & 46.4391 & 44.0983 & $\mathbf{4 0 . 9 5 3 9}$ \\
Kubergandian & 41.8466 & 48.3411 & 46.2039 & $\mathbf{4 2 . 8 0 2 1}$ \\
Murgabian & 86.3454 & 92.7912 & 90.6918 & $\mathbf{8 5 . 7 1 1}$ \\
Early Midian & 62.8149 & 69.1833 & 65.5872 & $\mathbf{6 2 . 5 2 4 4}$ \\
Dzhulfian & 61.6377 & 69.8441 & 66.5916 & $\mathbf{6 3 . 3 5 6 3}$ \\
\hline
\end{tabular}

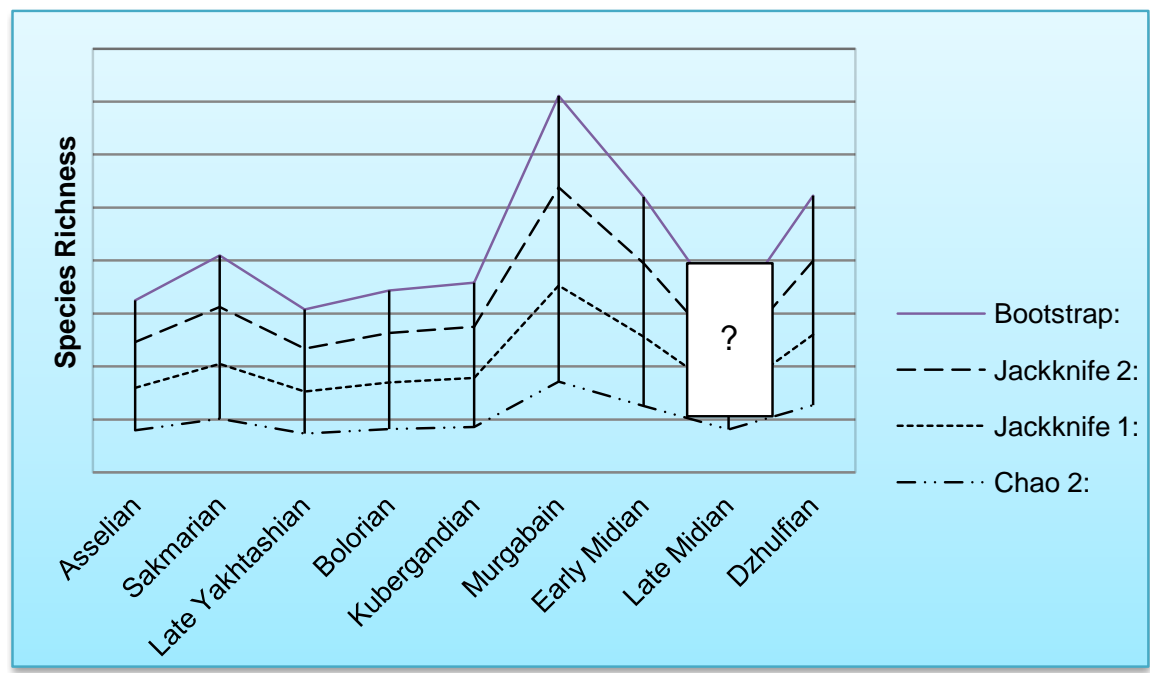

Figure 7. Change trend of Permian foraminifera richness from Asselian to Dzhulfian.

with high productivity in low latitude ocean [37]. This could be due to the stability of the environment and good living conditions. In this condition, species richness increase by the time and by increasing the number of species and size of the population. During the Midian a sharp drop in the diversity is seen. This drop is comparable to the same results for bivalves [38] and brachiopods [39] and probably caused by the kamura cooling event [37]. These are same as [40] results that showed two extinction in Maokovian and Changhsingian for both fusulinid and non-fusulinid foraminifera too. In Dzhulfian, foraminifer richness increases similar to other taxa at the global level. Diversity changes trend in this study is similar to the results of our previous study [41] at Abe-Garm section by using the method suggested by [42] for standing diversity calculation.

\section{References}

[1] Hammer, Ø., Harper, D. and Ryan, P.D. (2001) PAST: Paleontological Statistics Software Package for Education and Data Analysis. Palaeontologia Electronica, 4, 9. http://palaeo-electronica.org/2001_1/past/issue1_01.htm 
[2] Margalef, R. (1968) Perspective in Ecological Theory. University of Chicago Press, Chicago, $111 \mathrm{p}$.

[3] Washington, H.G. (1984) Diversity, Biotic and Similarity Indices. A Review with Special Relevance to Aquatic Ecosystems. Water Research, 18, 653-694.

[4] Whittaker, R.H. (1972) Evolution and Measurement of Species Diversity. Taxon, 21, 213-251. https://doi.org/10.2307/1218190

[5] Hammer, Ø. (2003) Biodiversity Curve for the Ordovician of Baltoscandia. Lethaia, 36, 305-313. https://doi.org/10.1080/00241160310006493

[6] Colwell, R.K. (2008) Range Model: Tools for Exploring and Assessing Geometric Constraints on Species Richness (the Mid-Domain Effect) along Transects. Ecography, 31, 4-7. https://doi.org/10.1111/j.2008.0906-7590.05347.x

[7] Hammer, Ø. and Harper, D. (2006) Paleontological Data Analysis. Blackwell Publishing, Malden, $351 \mathrm{p}$.

[8] Sepkoski, J. (1997) Presidential Address: Biodiversity: Past, Present, and Future. Journal of Paleontology, 71, 533-539. https://doi.org/10.1017/S0022336000040026

[9] Bentone, M.J. (1995) Diversification and Extinction in the History of Life. Science, 268, 52-58. https://doi.org/10.1126/science.7701342

[10] Ruban, D.A. and Tyszka, J. (2005) Diversity Dynamics and Mass Extinction of Early-Middle Jurassic Foraminifers. Paleogeography, Paleoclimatology, Paleoecology, 222, 239-343.

[11] Uhen, M.D. and Pyenson, N.D. (2007) Diversity Estimate, Biases, and Historiographic Effects. Paleontologia Electronic, 10, 22.

[12] Vilhena, D. and Smith, A.B. (2013) Spatial Bias in the Marine Fossil Record. PLoS $O N E$, 8, e74470. https://doi.org/10.1371/journal.pone.0074470

[13] Ruban, D.A. (2004) Diversity Dynamics of Early-Middle Jurassie Brachiopods of Caucasus. Acta Paleontological Polonica, 49, 2275-2820.

[14] Assereto, R. (1963) The Paleozoic Foraminifera in Central Elborz (Iran): Prelimnery Note. Rivista Italianadi Paleontologial Stratigrafia, 69, 503-543.

[15] Aghanabati, A. (2003) Geology of Iran. Publication of the Geological Survey of Iran, 586 p. (In Persian)

[16] Arefi Fard, S. and Davydov, V.I. (2014) New Permian Aliak and Kariz Now Formations, Alborz Basin, NE Iran: Correlation with the Zagros Mountain and Oman. Geological Journal, 50, 811-826.

[17] Nabavi, M. (1976) Introductory to the Geology of Iran. Geological Survey of Iran.

[18] Stoecklin, J. (1974a) Northern Iran: Alborz Mountains. In: Spencer, A.M., Ed., Mesozoic-Cenozoic Orogenic Belts, Data for Orogenic Studies, Alpine-Himalayan Orogens, Special Publication, Vol. 4, Geological Society, London, 213-234.

[19] Muttoni, M., Gaetani, D., Kent, V., Sciunnach, D., Angiolini, L., Berra, B., Garzanti, E., Mattei, M. and Zanchi, A. (2009) Opening of the Neo-Tethys Ocean and the Pangea B to Pangea A Transformation during the Permian Giovanni. GeoArabia, 14, 17-48.

[20] Smith, A.B. and McGowan, A.J. (2011) The Ties Linking Rock and Fossil Records and Why They Are Important for Palaeobiodiversity Studies. Geological Society London Special Publications, 358, 1-7. https://doi.org/10.1144/sp358.1

[21] Vaziri, H., Yao, A. and Kuwahara, K. (2005) Lithofacies and Microbiofacies (Foraminifers and Radiolarians) of the Permian Sequence in the Shalamzar Area, Central Alborz, North Iran. Journal of Geosciences, 48, 39-69. 
[22] Gaetani, M., Angiolini, A., Ueno, K., Nicora, A., Stephenson, M.H., Sciunnach, D., Rettori, R., Price, G. and Sabouri, J. (2009) Pennsylvanian-Early Triassic Stratigraphy in the Alborz Mountains (Iran). Geological Society, London, Special Publications, 312, 79-128. https://doi.org/10.1144/SP312.5

[23] Leven, E.Y. (1976) A Stage Scale for the Permian Deposits of Tethys. International Geology Review, 18, 807-819. https://doi.org/10.1080/00206817609471283

[24] Shabanian, R. (2010) Importace of Longenid Foraminifers in Permian of NW of Iran. The 1 st International Applied Geological Congress, Mashhad, 26-28 April 2010.

[25] Shabanian, R. and Saeidi, A. (2007) Permian Smaller Foraminifera Biozonation in Northwest of Iran. Peyke Noor Journal Science Fall, 1, 79-90. (In Persian)

[26] Davydov, V.I. and Blasky, P. (1996) Permian Fusulinids from the Koryak Terrane, Northeastern Russia and Their Paleobiogeographic a Finity. Jornal of Foraminiforal Reserch, 26, 213-243. https://doi.org/10.2113/gsjfr.26.3.213

[27] Baghebani, D. (1996) Biostratigraphy of Permian Foraminifera in Zagross (NW. IRAN). M.Sc Thesis, Tehran Islamic Azad University, Tehran. (In Persian)

[28] Bozorgnia, F. (1973) Paleozoic Foraminitional Biostratigraphy of Central and East Alborz Mountain Iran. N. I. O. C. Publication No. 4, Tehran.

[29] Filimonova, T.V. (2013) Smaller Foraminifers from the Permian of Central Iran. Stratigraphy and Geological Correlation, 21, 18-35. https://doi.org/10.1134/S0869593813010036

[30] Leven, E.Y. and Scherbovich, S.F. (1978) Fusulinids and Asselian Stratigraphy of Darvas. Moscow Society of Natural Studies, Geological Series. Nauka Publishing House, Moscow, 162 p. (In Russian)

[31] Filimonova, T.V. (2010) Smaller Foraminifers of the Lower Permian from Western Tethys. Stratigraphy and Geological Correlation, 18, 687-811. https://doi.org/10.1134/S0869593810070014

[32] Alipour, Z., Hosseini-Nezhad, S.M., Vachard, D. and Rashidi, K. (2012) The Latest Carboniferous-Early Permian Dorud Group of the Eastern Alborz (Iran): Biostratigraphy and Taxonomy of Smaller Foraminifers. Geological Journal, 48, 385-402. https://doi.org/10.1002/gj.2457

[33] Vaziri, H. (1992) Distribution of the Permian System in the Abyek-Hiv Area (Central Alborz). Ulum-e Zamin, 8, 44-59. (In Persian)

[34] Hamdi, B., Vaziri, H. and Rangrize-Azarfam, F. (2012) Biostratigraphy of the Ruteh Formation in North of Shalamzar, Central Alborz Baesd on Conodonts. Faslnemeh Zamin, 23, 37-43. (In Persian)

[35] Menning, M., Allekseev, A.S., Chuvashov, B.I., Davydov, V.I., Devuyst, F.-X., Forke, H.C., Grunt, T.A., Hance, L., Heckel, P.H., Izokh, N.G. and Jin, Y.-G. (2006) Global Time Scale and Regional Stratigraphic Reference Scale of Central and West Europe, Tethys, South China and North America as Used in the Devonian-CarboniferousPermian Correlation Chart. Palaeogeography Palaeoclimatology Palaeoecology, 240, 318-372.

[36] Vachard, D., Pille, L. and Gaillot, J. (2010) Palaeozoic Foraminifera: Systematics, Palaeoecology and Responses to the Global Changes. Revue de Micropaléontologie, 53, 209-254.

[37] Isozaki, Y., Kawahata, H. and Ota, A. (2007) A Unique Carbon Isotope Record across the Guadalupian-Lopingian (Middle-Upper Permian) Boundary in Mid-Oceanic. Journal of Asian Earth Sciences, 36, 407-412. 
[38] Isozaki, Y. and Aljinovic, D. (2009) End-Guadalopian Extinction of the Permian Gigantic Bivalve Alatoconchidae: End of Gigantism in Tropical Seas by Cooling. Paleogeogr, Paleoclim, Paleoecol, 284, 11-21.

[39] Shu-zhong, S. and Shi, G.R. (2002) Paleobiogeographical Extinction Patterns of Permian Brachiopods in the Asian-Western Pacific Region. Paleobiology, 28, 449463. https://doi.org/10.1666/0094-8373(2002)028<0449:PEPOPB >2.0.CO;2

[40] Tong, J. and Shi, G.R. (2000) Evolution of the Permian and Triassic Foraminifera in south China, Permium Triassic Evolution of Tethys and Western Circum-Pacific. Elsevier, Amsterdam, 291-307.

[41] Medadi, M., Mosaddegh, H., Aleali, M. and Majidifard, M.R. (2016) Paleobiodiversity of Permian (Yakhtashian-Dzhulfian) Small Foraminifera Base on Litho and Biostratigraphy in Abe-Garm (Gazvin-Iran) Section. Ulum-I Zamin, 26, 127-138. (In Persian)

[42] Foote, M. (2000) Origination and Extinctio Components of Taxonomic Diversity: General Problems. Paleobiology, 26, 578-605.

https://doi.org/10.1666/0094-8373(2000)026<0578:OAECOT >2.0.CO;2

\section{Appendix}

Table 1 and Tables 2(a)-2(f) Data sheet of absence/presence of foraminifera in samples. Table see:

https://drive.google.com/file/d/0B_IB7rdjbOS0eDlHVHRrWUxud0k/view

\section{Scientific Research Publishing}

Submit or recommend next manuscript to SCIRP and we will provide best service for you:

Accepting pre-submission inquiries through Email, Facebook, LinkedIn, Twitter, etc. A wide selection of journals (inclusive of 9 subjects, more than 200 journals)

Providing 24-hour high-quality service

User-friendly online submission system

Fair and swift peer-review system

Efficient typesetting and proofreading procedure

Display of the result of downloads and visits, as well as the number of cited articles

Maximum dissemination of your research work

Submit your manuscript at: http://papersubmission.scirp.org/

Or contact ojg@scirp.org 